\title{
Source Assessment and Analysis of Polycyclic Aromatic Hydrocarbon (PAH's) in the Oblogo Waste Disposal Sites and Some Water Bodies in and around the Accra Metropolis of Ghana
}

\author{
David Kofi ESSUMANG ${ }^{\mathbf{1}}$, Christian. Kweku ADOKOH ${ }^{\mathbf{1}}$, Joseph AFRIYIE ${ }^{\mathbf{2}}$, Esther MENSAH ${ }^{\mathbf{2}}$ \\ ${ }^{1}$ Environmental Research Group, Department of Chemistry, University of Cape Coast, Cape Coast, Ghana \\ ${ }^{2}$ Department of Laboratory Technology, University of Cape Coast, Cape Coast, Ghana \\ E-mail: \{kofiessumang, christattom\}@yahoo.com \\ Received September 22, 2009; revised October 16, 2009; accepted November 4, 2009
}

\begin{abstract}
The study looked at the levels of polycyclic aromatic hydrocarbons (PAHs) in leachates from a solid waste disposal site and an effluent from an oil refinery in some water bodies around Accra. Sixteen (PAHs) were extracted simultaneously by solid phase and analysis by gas chromatograph. The results of this study generally demonstrated that there were elevated levels of PAHs in the water sample of the Densu River, Chemu, Korle and Kpeshi Lagoons. The average concentration of PAHs in the water ranged from 0.000 of many of the PAHs to $0.552 \mu \mathrm{g} / \mathrm{L}$, for Acenapththene to $11.399 \mu \mathrm{g} / \mathrm{L}$ for Benzo (ghi) perylene of the Chemu Lagoon, $0.00 \mu \mathrm{g} / \mathrm{L}$ for Benzo (a) Pyrene to $8.800 \mu \mathrm{g} / \mathrm{L}$ for Benzo (ghi) perylene (Korle Lagoon) and $0.052 \mu \mathrm{g} / \mathrm{L}$ for Pyrene to $4.703 \mathrm{ug} / \mathrm{L}$ for Acenaphthylene of the Kpeshi Lagoon and $0.00 \mu \mathrm{g} / \mathrm{L}$ for pyrene to Acenaphthylene $2.926 \mu \mathrm{g} / \mathrm{L}$ of the Weija Dam. Concentrations ranging from below detection level to $14.587 \mu \mathrm{g} / \mathrm{L}$ were also recorded at the Oblogo solid waste dump and it's environ. The Weija dam supply over two million gallons of portable water daily to the people of Accra and the levels of the PAH determined is worrying, as a result, the Oblogoh disposal site ought to be re-located to avert any possible epidemic.
\end{abstract}

Keywords: Accra Metropolitan Assembly (AMA), Oblogo Dumping Site, Weija Dam, Densu River, PAHs, Chemu Lagoon, Korle Lagoon, Kpeshi Lagoon

\section{Introduction}

The disposal of wastes by land filling or land spreading is the ultimate fate of all solid wastes, whether they are residential wastes collected and transported directly to a landfill site, residual materials from materials recovery facilities (MRFs), residue from the combustion of solid waste, compost or other substances from various solid waste processing facilities. Disposing of solid waste in open dumps and burning of such solid waste, is the most common solid waste disposal method in Ghana. Open dump and burning of their content which is a health hazard, is not an acceptable method of solid waste disposal and must henceforth, be discouraged. For example, vinyl chloride and polythene form greater proportion of the solid waste in terms of volume as a result of the packaging industry [1]. Solid waste includes domestic refuse and discarded solid materials such as those from commercial, industrial and agricultural operations. They contain increasing amount of paper, cardboards, plastics, glass, packing materials and toxic substances. Combustion of these wastes completely and incompletely results in the production of toxic and corrosive chemicals such as PAH's, PCB's and hydrogen chloride just to mention a few [1].

Leachates from solid waste disposal sites which are chemicals removed from the waste as a result of water passing through is one of the major soil and water pollutants. These leachates are released into water bodies which tend to pollute them and needs to be monitored. A comprehensive waste management program must combine a variety of social, transportation, and treatment technologies. Components, in order of desirability, include prevention of wastes at the source; reuse, recycling, or composting; energy recovery; and putting in a landfill only those materials not amenable to other strategies [2]. 
The plan should consider impacts on air quality, water quality, traffic, noise, odor, socioeconomic effects, and community acceptance [3]. A modern sanitary landfill is not a dump; it is an engineered facility used for disposing of solid wastes on land without creating nuisances or hazards to public health or safety, such as the breeding of rats and insects and the contamination of ground water [4]. This is not the case in Ghana as open dumping and burning of solid waste is the only way of treating waste in Ghana.

Solid waste comes from various sources. Other forms of waste that can vary by location include agricultural waste, mining waste, and hazardous waste. Waste streams differ in the following attributes: physical (e.g., compatibility, density); combustion (temperature, residual ash percentage, heat content in BTUs); chemical composition, percentage of nitrogen, carbon, oxygen, chlorine; and concentrations of toxic polycyclic aromatic hydrocarbons (PAHs) and metals; potential for recycling various components; and ease of separation [3].

Polycyclic aromatic hydrocarbons (PAHs) are another group of dangerous compounds which man introduces into the environment in large quantities with little or no awareness. These are a suit of organic compounds release into the environment as gas particles during incomplete combustion of organic material. PAHs have a number of sources including: Mobil sources such as cars, buses, trucks, ships, and aircrafts; industrial sources such as power generation, steelworks, and coke ovens, aluminum production, and cement kilns, oil refining as well as waste from incineration. Domestic sources include combustion for heating and cooking especially solid fuel using coal and wood. Fires and smoke resulting from burning of vegetation in agricultural process, bushfires, grilling of food, or tobacco smoke [5].

These compounds (PAHs) are also cumulative and may cause a whole lot of health related complications ranging from mutations in lower animals to cancerous cells in humans $[5,6]$. Other environmental factors affect the distribution of PAHs. For example it has been proved by Shahunthala 2006 that increases in salinity decreases the exposure of PAHs and also dispersant effectiveness decreased only at the highest salinity. Hence, risks to fish of PAH from dispersed oil will be greatest in coastal waters where salinities are low [7].

The smallest member of the PAH group is naphthalene, a two-ring compound, which is gaseous at room temperature. PAHs are usually found as a mixture containing two or more of these compounds, such as soot. PAHs are highly potent carcinogens that can produce tumors in some organisms at even single doses; but other non-cancer-causing effects are not well understood [8]. PAHs can occur naturally or can be man-made. Manufactured PAHs usually exist as colorless, white, or pale yellow-green solids. PAHs are commonly found in coal tar, crude oil, creosote, and roofing tar. Some are used in medicines or to make dyes, plastics, and pesticides [9]. Man made sources such as automobile exhausts and coal burning contribute far more PAHs to the environment than natural sources.

PAHs are dangerous, thus, increases risk of cancer and creates advance glycogen end product which leads to an increased risk of coronary heart disease and diabetes [10]. Laboratory and field evidence indicates that PAHs induce neoplastic and genotoxic effects in aquatic biota. Data from mammals indicate that these animals may be susceptible to such effects, but no studies were identified documenting such effects in wild mammals. PAHs known for their carcinogenic, mutagenic (gene mutation causing agent) and teratogenic (chemicals that affect the normal development of foetus) properties are Benzo[a] pyrene, Benzo[a]anthracene chrysene, Benzo[b] fluoranthene, Benzo [j]fluoranthene, Benzo[k] fluoranthene, Benzo [ghi] perilene, coronene, Dibenz[a,h] anthracene $\left(\mathrm{C}_{20} \mathrm{H}_{14}\right)$, Indeno [1,2,3-cd]pyrene $\left(\mathrm{C}_{22} \mathrm{H}_{12}\right)$ and ovalene. Mice that were fed high levels of one $\mathrm{PAH}$ during pregnancy had difficulty reproducing and so did their offspring. These offspring also had higher rates of birth defects and lower body weights. It is not known whether these effects occur in humans. Animal studies have also shown that PAHs can cause harmful effects on the skin, body fluids, and ability to fight disease after both shortand long- term exposure. But these effects have not been seen in human beings. Some people who have breathed or touched mixtures of PAHs and other chemicals for long periods of time have developed cancer [11].

Some PAHs have caused cancer in laboratory animals when they breathed air containing them (lung cancer), ingested them in food (stomach cancer), or had them applied to their skin (skin cancer). A research conducted by the Agency for Toxic Substances and Disease Registry [12] under the Canadian department of Health and Human services in the year 2007, ranked PAHs as the sixth most hazardous substance among a number of 275 compounds on which the research was conducted. According to the research the first six most hazardous compounds were arsenic, lead, mercury, vinyl chloride, polychlorinated biphenyls and PAHs.

Although solid waste can be properly treated before disposal, solid waste problem arise from; rapid increase of human population, aggregation of people in urban areas (rapid advance in technology and social attitudes).

Solid waste materials pose a serious threat because the leach from it remain in place for a relatively longer period of time unless removed, burned or otherwise destroyed [13]. The combustion of solid waste leads to the formation of PAHs and the main problem of this study is to analyze the concentration of $\mathrm{PAH}$ in the leach from solid waste disposal site since burning of solid waste is the only way of treating waste in Ghana. The leachates from this waste deposition site run into water bodies eg. Densu River flows to join Weija Dam and other lagoons 
in Accra Metropolitan Assembly. The Ghanaian ecosystem plays host to a number of lagoons which serve various functions. The most important of them is being the home for various species of fish. For example the tilapia which is a delicacy in most Ghanaian communities finds its haven in most of the lagoons. The Kpeshie, Korle, and the Chemu lagoons (all in the greater Accra region), the Fosu lagoon (central region) and others throughout the country until recently had been a good sources of fish (mainly tilapia). The Korle lagoon, owing to its extent of pollution, not much living things were present in it for some years, it has recently been dredged. Its scent wafts back to envelope the adjoining shanty town which is the home of hundreds of families who, because they have no sanitation facilities, have turned the shores of the lagoon into a giant latrine. Large portions of the Kpeshie lagoon and it mangrove at La an Accra suburb are being reclaimed and sold to individuals for residential and business development purposes. As a result the lagoon and it mangrove are disappearing fast. Extensive portion of the lagoon have been filled with sand, construction debris and garbage ready to be sold to prospective buyers.

In addition the Korle, Kpeshie and the Chemu lagoons are close to solid waste disposal site and are near major roads used by various kinds of motorists which emit smoke continuously into the environment. Also near the Korle lagoon is located a slaughter house which produces smoke continuously from the processing of hide using car tire. The Chemu lagoon located in Tema New town is being exposed to smoke from vehicles. It is also close to the Tema oil refinery which continuously emits smoke into the environment. Due to the above mentioned facts it is suspected that the Korle, Kpeshie, and the Chemu lagoons may have considerable amounts of PAHs dissolved in them. It is in this views that this study has been designed to determine the level and distribution of PAHs in leachates from the Oblogo solid waste disposal site, waters of the Korle, Kpeshie and the Chemu lagoons and their interrelationships with physiochemical parameters such as $\mathrm{pH}$, salinity, chloride, turbidity and conductivity in the greater Accra regions of Ghana.

\section{Materials and Methods}

\subsection{Sample Collection}

Samples were collected from Oblogo solid disposal waste site, Weija dam and the down stream of River Densu (thus, the mixture of the Weija dam and leach) as well as three lagoons namely, Kpeshie, Korle and the Chemu lagoons. These samples were taken from different points on the lagoons so as to get fairly representative samples of each of the lagoons. Three samples were taken from each of the lagoons and four samples from oblogo solid waste site bringing the total number of samples taken to thirteen. Since all the three lagoons were connected directly to the sea, all the first samples taken were made closer to the sea and the other two taken from different intervals $(0.5 \mathrm{~km})$ from the bank of the lagoons.

Clean amber glass bottles were used in the collection of the sample to prevent sunrays and it effect on any present bacteria. The amber glass bottles were washed with detergents (liquid soap) and rinsed with lot of water to remove any trace of soap, distilled water is then used to wash the bottles to remove ions present. The water samples were then collected into the bottles, covered in an ice chest with ice and transported to the laboratory for analysis.

\subsection{Methodology}

The research was carried out at the Centre for Scientific and Industrial Research (CSIR), Environmental Division (ED), Water Research Institute (WRI), Organic Laboratory. The parameters measured includes; conductivity, $\mathrm{pH}$, salinity and Polycyclic Aromatic Hydrocarbons.

\subsection{Conductivity}

The conductivity was measured by mixing the sample very well and pouring into a clean cup. The conductivity meter was immersed in the water sample and the cup swirled to get the appropriate reading and recorded in microsiemens $(\mu \mathrm{s})$. The instrument was calibrated using standard $\mathrm{KCl}(0.01 \mathrm{M})$ which has a conductivity of $141 \mu \mathrm{s} / \mathrm{cm}$ at $25^{\circ} \mathrm{C}$, each reading was done three times [14].

For theoretical purpose; $\mathrm{K}=\mathrm{km} \times \mathrm{c} /(1+0.0191)(\mathrm{T}-25)$

Where, $\mathrm{Km}=$ measured conductivity, $\mathrm{mS} / \mathrm{cm}$ at $25^{\circ} \mathrm{C}$

$\mathrm{C}=$ cell constant, $\mathrm{cm}^{-1}, \mathrm{~T}=$ temperature of sample

\section{4. pH}

The $\mathrm{pH}$ was determined by using the $\mathrm{pH}$ meter and combination electrode for measurement, the electrode was immersed into the water sample and the cup swirled to get accurate results. The $\mathrm{pH}$ was recorded in $\mathrm{pH}$ units. Calibrate by; washing the electrode of the meter very well with distilled water, the electrode is first calibrated against a pH buffer 4 then 9 and then 7, a reference solution of known $\mathrm{pH}$ was measured to check the sensitivity and accuracy of the electrode.

\subsection{Salinity}

For salinity, chloride was determined. $50 \mathrm{ml}$ of the sample was used for the determination of chloride but due to high conductivity of the Oblogo leachates and diluted Oblogo leachates, $1 \mathrm{ml}$ of the sample was used and di- 
luted to $50 \mathrm{ml}$ with distilled water. When diluted, endpoint was easy to attain. $1 \mathrm{ml}$ of potassium chromate was added and titrated against $0.0141 \mathrm{M}$ silver nitrate to obtain a pinkish yellow endpoint. The reading on the $50 \mathrm{ml}$ graduated burette was recorded.

To calculate for chloride; $\mathrm{MgCl}^{-} / \mathrm{L}=(\mathrm{A}-\mathrm{B}) \times \mathrm{M} \times 3540$ ml sample

$A=m l$ titration for sample

$\mathrm{B}=\mathrm{ml}$ titration for blank

$\mathrm{M}=$ molarity of $\mathrm{AgNO}_{3}$

To ensure accuracy of work, the $\mathrm{AgNO}_{3}$ was standardized with $\mathrm{NaCl}$; thus

About $10 \mathrm{~mL}$ of standard $\mathrm{NaCl}$ solution was measured (pipetted) into a flask and 2 drops of potassium chromate indicator was added. This was titrated with the $\mathrm{AgNO}_{3}$ solution to obtain a pinkish yellow end point.

To calculate for salinity;

$\mathrm{S} \%=0.03+1.805\left(\mathrm{Cl}^{-} \times 1.00045\right) / 1000[15]$.

\subsection{Extraction of PAH from Water}

For PAHs, $1000 \mathrm{ml}$ (1L) of water sample was poured into a separating funnel. $50 \mathrm{ml}$ of dichloromethane was added followed by $0.2 \mathrm{ml}$ internal standard to correct errors using micro syringe. The content of the separating funnel was shaken well for the dichloromethane to extract as much organic components as possible from the water sample. The separating funnel was left undisturbed on a retort stand for sometime, so that the mixture separates into the organic and water layer. The separating funnel was then opened to drain the water layer. The organic layer was drained through a glass funnel which was plugged with glass wool, filter paper and sodium sulphate into a Zymark tube. The sodium sulphate was used to absorb water that might be present in the organic layer.

A second extraction was carried out using $50 \mathrm{~mL}$ of dichloromethane and the extract was added to the one in the Zymark tube. One drop of iso-octane was added to the contents in the Zymark tube and was placed into a Turbo Evaporation Unit to reduce the volume to $1 \mathrm{ml}$ by evaporation. The iso-octane served as a keeper to prevent evaporation of the needed components. The extract in the Zymark tube was then transferred into test tubes using pasture pipettes. The Zymark tube was washed with $2 \mathrm{ml}$ of dichloromethane and added to the content in the test tube. The test tube was heated in a block heater and a gentle steam of nitrogen was used to reduce the volume to $0.5 \mathrm{ml} .1 \mathrm{ml}$ of cyclohexane was added and the mixture was evaporated to dryness followed by the addition of $0.5 \mathrm{ml}$ hexane [16-17].

\subsection{Clean-Up}

Most of the unwanted components were removed from the extract leaving the components of interest. This was achieved by using solid phase extraction tubes containing $500 \mathrm{mg}$ florisil, $3 \mathrm{ml}$ by volume. This solid phase was conditioned using $6 \mathrm{ml}$ of hexane. $0.5 \mathrm{~mL}$ of the extract was added and eluted with $6.0 \mathrm{~mL}$ hexane into a test tube. The PAHs in the extract was held by the florisil column. The column was eluted again using 20\% dichloromethane in hexane into another test tube and this fraction contained the PAHs. The volume was reduced to $0.5 \mathrm{ml}$ and was transferred into sample vials for gas chromatography run [11].

\subsection{Gas Chromatography}

Gas chromatography (GC) is a common confirmation test. GC analysis separates all of the components in a sample and provides a representative spectral output. Before the sample was analyzed, the instrument was tuned and calibrated. Tuning was accomplished using specific concentrations of Decafluorotriphenylphosphine and p-Bromofluorobenzene to test the instruments reporting accuracy. The sample vials that contained the extracts were arranged on a plate at the injection point and the injection was done automatically by the machine.

The sample was introduced as a vapor onto the chromatographic column. On the column, the solubility of each component in the gas phase was dependent on it vapor pressure, which was in turn a function of the column temperature and the affinity between the compound and the stationary phase. To ensure proper separation, the sample must enter the column in a discreet, compact pocket. The gas chromatography instrument uses the flame ionization detector with the model $6890 \mathrm{~N}$ to measure the different compounds as they emerge from the column. The principle behind Gas Chromatography states that the rate of migration of the solute depends upon the rate of interaction of the solute with a two phase, the mobile phase and the stationary phase as the compound travels through the supporting medium.

\section{Results and Discussions}

Reliability of any analytical results can be verified using certain indicators which include the method and equipment used, accuracy, precision, etc. The precision and suitability of the method to the measuring equipment used, was initially established using the certified reference material. This was done by using the reference material alone and also treated as a sample. The percentage recoveries were then calculated. The method verification and sample results are tabulated in Table 1 below.

\subsection{Data Analysis}

Estimation of PAHs was done by expression: Concentra- 
Table 1. Summary of system suitability and percentage recovery using certified reference material.

\begin{tabular}{|c|c|c|c|c|c|c|c|c|c|}
\hline \multirow[t]{2}{*}{ COMPOUND NAME } & \multicolumn{2}{|c|}{$\begin{array}{c}\text { AMOUNT } \\
\mu \mathrm{g} / \mathrm{ml}\end{array}$} & \multicolumn{2}{|c|}{$\underset{(\mu \mathrm{g} / \mathrm{ml})}{\mathrm{AVE}}$} & \multicolumn{2}{|c|}{$\begin{array}{c}\text { TRUE Rel. Value } \\
\text { Error }(\%) \\
\mu \mathrm{g} / \mathrm{ml}\end{array}$} & \multicolumn{2}{|c|}{$\begin{array}{c}\text { Stand. \% recovery } \\
\text { Dev. }\end{array}$} & \multirow[t]{2}{*}{$\begin{array}{c}\text { Rel. } \\
\text { Stand. } \\
\text { Dev. \% }\end{array}$} \\
\hline & 1 & 2 & 3 & & & & & & \\
\hline Naphthalene & 14.2 & 14.3 & 14.2 & 14.2 & 15.0 & -5.3 & 0.0577 & 94.67 & 0.4063 \\
\hline 2- Methylnaphthalene & 14.7 & 14.8 & 14.8 & 14.8 & 15.0 & -1.3 & 0.0577 & 98.67 & 0.3899 \\
\hline 1-Methylphthalene & 14.7 & 14.8 & 14.7 & 14.7 & 15.0 & -2.0 & 0.0577 & 98.00 & 0.3925 \\
\hline Biphenyl & 14.8 & 15.2 & 14.8 & 14.9 & 15.0 & -0.7 & 0.2309 & 99.33 & 1.5497 \\
\hline 2,6-Dimethylnaphthalene & 14.8 & 14.9 & 14.8 & 14.8 & 15.0 & -1.3 & 0.0577 & 98.67 & 0.3899 \\
\hline Acenaphthylene & 14.8 & 14.9 & 14.7 & 14.8 & 15.0 & -1.3 & 0.1000 & 98.67 & 0.6757 \\
\hline Acenaphthene & 14.8 & 14.8 & 14.8 & 14.8 & 15.0 & -1.3 & 0.0000 & 98.67 & 0.0000 \\
\hline 2,3,5-Trimethylnaphthalen & 14.7 & 14.7 & 14.7 & 14.7 & 15.0 & -2.0 & 0.0000 & 98.00 & 0.0000 \\
\hline Fluorene & 14.7 & 14.9 & 14.8 & 14.8 & 15.0 & -1.3 & 0.1000 & 98.67 & 0.6757 \\
\hline Phenanthrene & 14.7 & 14.8 & 14.8 & 14.8 & 15.0 & -1.3 & 0.0577 & 98.67 & 0.3899 \\
\hline Anthracene & 14.8 & 14.9 & 14.9 & 14.9 & 15.0 & -0.7 & 0.0577 & 99.33 & 0.3872 \\
\hline 1-Methylphenanthrene & $12.8 *$ & 14.7 & 14.7 & 14.7 & 15.0 & -2.0 & 0.0000 & 98.00 & 0.0000 \\
\hline IS 3,6-DMP & 10.0 & 10.0 & 10.0 & 10.0 & 10.0 & 0.0 & 0.0000 & 100.00 & 0.0000 \\
\hline Fluoranthene & 14.8 & 14.8 & 14.8 & 14.8 & 15.0 & -1.3 & 0.0000 & 98.67 & 0.0000 \\
\hline Pyrene & 14.2 & 14.2 & 14.2 & 14.2 & 15.0 & -5.3 & 0.0000 & 94.67 & 0.0000 \\
\hline Benzo(a)anthracene & 14.5 & 14.5 & 14.4 & 14.5 & 15.0 & -3.3 & 0.0577 & 96.67 & 0.3979 \\
\hline Chrysene & 14.6 & 14.5 & 14.5 & 14.5 & 15.0 & -3.3 & 0.0577 & 96.67 & 0.3979 \\
\hline IS BB-Biphenyl & 10.0 & 10.0 & 10.0 & 10.0 & 10.0 & 0.0 & 0.0000 & 100.00 & 0.0000 \\
\hline Benzo(b)fluoranthene & 15.3 & 15.0 & 15.3 & 15.2 & 15.0 & 1.3 & 0.1732 & 101.33 & 1.1395 \\
\hline Benzo(k)fluoranthene & 14.1 & 14.0 & 14.1 & 14.1 & 15.0 & -6.0 & 0.0577 & 94.00 & 0.4092 \\
\hline Benzo(e)pyrene & 14.7 & 14.3 & 14.5 & 14.5 & 15.0 & -3.3 & 0.2000 & 96.67 & 1.3793 \\
\hline Benzo(a)pyrene & 14.8 & 14.4 & 14.3 & 14.5 & 15.0 & -3.3 & 0.2646 & 96.67 & 1.8248 \\
\hline Perylene & 14.8 & 14.4 & 14.7 & 14.6 & 15.0 & -2.7 & 0.2082 & 97.33 & 1.4260 \\
\hline Indeno( $1,2,3 \mathrm{~cd})$ pyrene & 15.3 & 14.1 & 14.9 & 14.8 & 15.0 & -1.3 & 0.6110 & 98.67 & 4.1284 \\
\hline Dibenz(a,h)anthracene & 14.1 & 13.4 & 14.8 & 14.1 & 15.0 & -6.0 & 0.7000 & 94.00 & 4.9645 \\
\hline Benzo(g,h,i)perylene & 14.8 & 13.6 & 14.6 & 14.3 & 15.0 & -4.7 & 0.6429 & 95.33 & 4.4958 \\
\hline
\end{tabular}

* Statistically rejected data as an outlier using Q-Test.

Table 2. Summary of physico-chemical parameters (levels) of the water samples.

\begin{tabular}{|c|c|c|c|}
\hline Name of sample & $\begin{array}{l}\text { Average } \\
\text { Conductivity } \\
(\mathrm{S} / \mathrm{m})\end{array}$ & $\begin{array}{l}\text { Average } \\
\text { (pH unit) }\end{array}$ & $\begin{array}{c}\text { Average } \\
\text { Salinity } \\
\text { (ppm) }\end{array}$ \\
\hline Leach from Oblogo solid waste site & 1.333 & 8.43 & $3.5 \times 10-3$ \\
\hline Leach diluted with rain water & 0.976 & 8.38 & $2.3 \times 10-3$ \\
\hline Down stream of river Densu & 0.025 & 7.75 & $7.7 \times 10-5$ \\
\hline Weija dam & 0.027 & 7.51 & $7.5 \times 10-5$ \\
\hline Chemu Lagoon & 5.677 & 7.687 & 5.72 \\
\hline Korle Lagoon & 40.83 & 7.52 & 26.53 \\
\hline Kpeshie Lagoon & 40.50 & 7.52 & 26.20 \\
\hline
\end{tabular}

Table 2 shows the detailed data of the physicochemical properties of the sampling site, the average $\mathrm{pH}$ was around neutral with a value ranging 7.51 to 8.43 . The Chemu, korle and kpeshie lagoons recorded an average high conductivity of $5.677,40.83$ and $40.50 \mathrm{~S} / \mathrm{m}$ respectively, while samples from oblogo sampling sites recorded very low conductivity range of $0.027-1.333 \mathrm{~S} / \mathrm{m}$. The very high value in the Lagoons is expected because the Chemu as well as the other two lagoons flow into the sea and the concentration of dissolved ions is expected to be very high which has been proved by high salinity values $(5.72-26.53)$ recorded as shown in Table 3 above. 
Table 3. Summary of mean concentrations of PAHs in the Oblogo dumping sites and its environ.

\begin{tabular}{|c|c|c|c|c|c|}
\hline \multicolumn{6}{|c|}{ Mean Concentration in $\mu \mathrm{g} / \mathrm{L} \pm \mathrm{SD}$} \\
\hline PAHs & $\begin{array}{l}\text { Leach from } \\
\text { Oblogo solid waste } \\
\text { disposal site }\end{array}$ & $\begin{array}{l}\text { Leach diluted } \\
\text { with rain } \\
\text { water }\end{array}$ & $\begin{array}{c}\text { Down stream } \\
\text { of River Densu }\end{array}$ & $\begin{array}{c}\text { Weija } \\
\text { dam site }\end{array}$ & Average \\
\hline Naphthalene & 2.248 & 2.165 & 2.42 & 2.171 & $2.251 \pm$ \\
\hline Acenaphthylene & 9.878 & 2.495 & 1.318 & 2.926 & $4.154 \pm 3.87$ \\
\hline Acenaphthene & 2.624 & 14.587 & 5.091 & 0.051 & $5.588 \pm 6.342$ \\
\hline Fluorine & 2.715 & 0.648 & 13.539 & 0.691 & $4.398 \pm 6.169$ \\
\hline Phenanthrene & 0 & 1.199 & 5.188 & 0.141 & $2.531 \pm 2.286$ \\
\hline Anthracene & 5.368 & 2.43 & 6.382 & 0.486 & $3.667 \pm 2.703$ \\
\hline Fluoranthene & 1.912 & 2.548 & 1.412 & 1.638 & $1.878 \pm 0.492$ \\
\hline Pyrene & 0.029 & 0 & 0.105 & 0 & $0.045 \pm 0.054$ \\
\hline Benzo[a] anthracene & 0 & 0.323 & 3.018 & 0.03 & $1.124 \pm 1.647$ \\
\hline Chrysene & 0 & 0 & 1.295 & 0 & $1.295 \pm 0.000$ \\
\hline Benzo[b] fluoranthene & 4.921 & 1.26 & 0.88 & 1.156 & $2.054 \pm 1.918$ \\
\hline Benzo[k] fluoranthene & 0 & 0 & 0.059 & 0.058 & $0.058 \pm 7.071$ \\
\hline Benzo[a] pyrene & 0.199 & 0 & 0 & 0.085 & $0.071 \pm 0.081$ \\
\hline $\begin{array}{c}\text { Indeno }[1,2,3-c d] \\
\text { pyrene }\end{array}$ & 0.779 & 0 & 1.788 & 0 & $0.856 \pm 0.713$ \\
\hline $\begin{array}{l}\text { Dibenz }[\mathrm{a}, \mathrm{h}] \text { anthra- } \\
\text { cene }\end{array}$ & 1.731 & 0 & 0.093 & 0 & $0.608 \pm 1.158$ \\
\hline Benzo[ghi] perylene & 1.905 & 1.042 & 0.647 & 0.626 & $1.055 \pm 0.699$ \\
\hline Total & 37.906 & 28.699 & 43.235 & 10.058 & 31.633 \\
\hline
\end{tabular}

tion $=$ Amount $(\mu \mathrm{g} / \mathrm{ml}) X$ Final volume of Extract $(\mathrm{ml}) /$ Weight taken $(\mathrm{g})$

From Table 3, the PAHs distribution in the leach from Oblogo solid waste site has been observed with Acenaphthylene recording the highest concentration of 9.878 $\mu \mathrm{g} / \mathrm{L}$ and Pyrene with the least concentration of 0.029 $\mu \mathrm{g} / \mathrm{L}$. The carcinogenic PAH detected at this site were Benzo[b]fluoranthene, Benzo[a]pyrene, Indino [1,2,3-cd] perilene and Dibenz[a,h]anthracene with concentration of $4.921 \mu \mathrm{g} / \mathrm{L}, 0.199 \mu \mathrm{g} / \mathrm{L}, 0.779 \mu \mathrm{g} / \mathrm{L}, 1.731 \mu \mathrm{g} / \mathrm{L}$ respectively (Table 3 ). These concentrations may resulted from the combustion of the solid waste with the presence of domestic refuse and discarded solid materials such as those from commercial, industrial and agricultural operations: they contain increasing amount of paper, cardboards, plastics, glass, packing materials and toxic substances.

The PAHs distribution in the leach diluted with rain water has been observed with Acenaphthene recording the highest concentration of $14.587 \mu \mathrm{g} / \mathrm{L}$ and Benzo (a) anthracene with the least concentration level of 0.323 $\mu \mathrm{g} / \mathrm{L}$. The carcinogenic PAHs detected at this site were Benzo (a) anthracene and Benzo (b) fluoranthene with concentrations of $0.323 \mu \mathrm{g} / \mathrm{L}$ and $1.26 \mu \mathrm{g} / \mathrm{L}$ respectively. All the concentrations detected at this site were above the WHO's limit of $0.05 \mu \mathrm{g} / \mathrm{L}$ [13]; this indicates high level of contamination in the leach diluted with rain water. The higher concentration of some PAHs in the diluted leach with rain water shows how the atmosphere has been polluted through anthropogenic source (automobiles, burning of biogas, industrial activities etc). PAH distribution in the downstream of river Densu has been observed with Fluorine recording the highest concentration of $13.539 \mu \mathrm{g} / \mathrm{L}$ and Benzo[k] fluoranthene with the least concentration of $0.059 \mu \mathrm{g} / \mathrm{L}$. The carcinogenic PAHs detected at this site were chrysene, Benzo [a] anthracene, Benzo[b] fluoranthene and Benzo [k] fluoranthene Indino[1,2,3-cd]pyrene and Dibenz[a,h] anthracene with concentrations of $1.295 \mu \mathrm{g} / \mathrm{L}, 3.018 \mu \mathrm{g} / \mathrm{L}, 0.88 \mu \mathrm{g} /$ 
$\mathrm{L}, 0.059 \mu \mathrm{g} / \mathrm{L}$ and $1.788 \mu \mathrm{g} / \mathrm{L}$ and $0.093 \mu \mathrm{g} / \mathrm{L}$ respectively (Table 3).

All the concentrations detected at this site were also above the WHO's limit of $0.05 \mu \mathrm{g} / \mathrm{L}$ [13]; this indicates high level of contamination in the downstream of river Densu. These concentrations could be due to the leach joining the downstream of river Densu. PAH distribution in the Weija dam has been observed with Acenaphthylene recording the highest concentration of $2.926 \mu \mathrm{g} / \mathrm{L}$ and Benzo[a] anthracene with the least concentration of $0.030 \mu \mathrm{g} / \mathrm{L}$ (Table 3). The carcinogenic PAHs detected at this site were Benzo[a] anthracene, Benzo[b] fluoranthene and Benzo[k] fluoranthene and Benzo[a]pyrene with concentrations of $0.030 \mu \mathrm{g} / \mathrm{L}, 1.156 \mu \mathrm{g} / \mathrm{L}$ and $0.058 \mu \mathrm{g} / \mathrm{L}$ and $0.085 \mu \mathrm{g} / \mathrm{L}$ respectively.

Table 4 compares the average concentration of the individual PAHs compounds in the three lagoons. In all, the Chemu lagoon recorded the highest PAHs concentration with a total of $61.712 \mu \mathrm{g} / \mathrm{L}$ followed by the Korle lagoon and then the Kpeshie lagoon with total PAHs of $38.889 \mathrm{ug} / \mathrm{L}$ and $34.09 \mu \mathrm{g} / \mathrm{L}$ respectively. Both the Chemu and the Korle lagoons had Benzo (ghi) perylene as the compound with the highest concentration, whiles the Kpeshie lagoon on the other hand had Acenaphthylene as the compound with the highest average concentration. Samples from Oblogo damping site and it's environ recorded appreciably PAH values with $14.587 \mu \mathrm{g} / \mathrm{L}$ of Acenaphthylene being the highest compared to the three lagoons. This could be as a result of the low salinity nature of the water which may increase dispersant effectiveness. Hence, risks to fish of PAH from other sources would be greatest in coastal waters where salinities are low and however fish from Densu River and Weija Dam may be at risk [18].

The average concentration of the PAHs in the lagoon water ranged from $0.552 \mu \mathrm{g} / \mathrm{L}$, for Acenapththene to $11.399 \mathrm{ug} / \mathrm{L}$ for Benzo (b) fluoranthene. Other PAHs which recorded extremely high average values in the Chemu lagoon are Acenaphthylene $(9.146 \mu \mathrm{g} / \mathrm{L})$, Benzo (k) fluora- nthene $(6.644 \mu \mathrm{g} / \mathrm{L})$, Benzo (b) fluoranthene $(9.948 \mu \mathrm{g} / \mathrm{L})$. This high PAHs contamination may result from the fact that Chemu lagoon has various refuse dumping sites along the bank where continuous burning of refuse are carried out, also fish smoking homes are located near the banks. In addition smoke emitting vehicles that continuously pry the road near and across some parts of the lagoon coupled with smoke emission from the chimney of the Tema oil refinery may be the major contributing factors to the high levels of contamination in the Chemu lagoon.

The average concentration of PAHs in the water sample of the Korle lagoon ranges from $0.00 \mathrm{ug} / \mathrm{L}$ for Benzo (a) pyrene to $8.800 \mu \mathrm{g} / \mathrm{L}$ for Benzo (ghi) perylene. Apart from Benzo (a) pyrene which recorded zero micrograms per liter in the Korle lagoon. Other PAHs which recorded extremely high values in the Korle lagoon include Anthracene, Fluoranthene, Chrysene, Dibenz $(a, h)$ anthra- cene and Acenaphthylene with average concentrations of $8.310 \mu \mathrm{g} / \mathrm{L}, 7.796 \mu \mathrm{g} / \mathrm{L}, 3.099 \mu \mathrm{g} / \mathrm{L}, 6.198 \mu \mathrm{g} / \mathrm{L}, 2.978-$ $\mu \mathrm{g} / \mathrm{L}$ respectively (Table 4). The Korle lagoon stretches along the Accra Korlebu high-way thus receiving heavy smoke from vehicles that move constantly on the road. Aside this problem at some distance from the lagoon, there is a slaughter house which also produces thick smoke that may have caused PAHs accumulation in the lagoon. It is also suspected that effluent from the Korlebu Teaching Hospital may get into the lagoon which may also contribute to the level of pollution. In general it is gratifying to note that the level of PAHs in Chemu lagoon is relatively higher than that of the Korle lagoon. This may be due to the dredging process that was ongoing during the time of sampling at the Korle lagoon. In spite of this reduction, all PAH compounds analyzed with the exception of Benzo (a) pyrene exceeded the WHO acceptable limits and thus consumption of fish or any other food substances from the lagoon may prove dangerous to the health of the consumers.

Table 4 showed a compilation of PAH concentrations from the Kpeshie lagoon. The average concentrations of PAHs in the waters of the Kpeshie lagoon range from $0.052 \mu \mathrm{g} / \mathrm{L}$ for Pyrene to $4.703 \mu \mathrm{g} / \mathrm{L}$ for Acenaphthylene. Other PAHs which recorded extremely high average values in the Kpeshie lagoon include Benzo (b) fluoranthene, Acenapththene, Chrysene, Benzo (ghi) perylene, Anthracene, Fluorine with average concentrations of $4,680 \mu \mathrm{g} / \mathrm{L}, \quad 4.003 \mu \mathrm{g} / \mathrm{L}$, and $4.374 \mu \mathrm{g} / \mathrm{L}, \quad 7.847 \mu \mathrm{g} / \mathrm{L}$, $3.364 \mu \mathrm{g} / \mathrm{L}, 1.112 \mathrm{ug} / \mathrm{L}$ respectively. Along the banks of the Kpeshie lagoon is stretch of mangroves which is used as hiding places for petty criminals therefore smoking of cigarettes and Indian hemp at these places is routine. Again some parts of the Kpeshie lagoon stretches along the Accra-Tema high way near La. It is interesting to note that just at the portion where the lagoon begins is also the starting point of a very serious traffic jam that has terrorized the inhabitants of Teshie and Nungua for years. Another very important consideration about the location of the lagoon its closeness to the Accra International Trade Fair Center. Waste discharged from the trade fair center to the lagoon might have also increased the level of PAH contaminations. It is therefore not far from right to say that these two major activities may have contributed to the PAH levels in the Kpeshie lagoon

The concentration levels of PAHs detected were slightly varied from the location. The commonly found PAH compounds in water samples were acenapthene, fluorine, phenanthene, fluoranthene, pyrene, benzo [b] fluoranthene. Naphthalene, acenaphthylene, benzo [a] pyrene and benzo [ghi] perylene were found in all samples taken from oblogo dumping site and it's environ. In the case of the three lagoons all PAHs were detected. There were huge variations between sites for some compounds (e.g., acenaphthene, acenaphthylene and benzo [a]pyrene), whereas the concentrations of the majority of 
Table 4. Summary of PAH concentrations $(\mu \mathrm{g} / \mathrm{L}) \pm$ SD comparison from the Chemu, Korle and Kpeshie Lagoons.

\begin{tabular}{llcc}
\hline \multicolumn{1}{c}{ PAH } & \multicolumn{1}{c}{ CONCENTRATIONS $(\mu \mathrm{g} / \mathrm{L}) \pm$ SD } \\
\hline Naphthalene & CHEMU & KORLE & KPESHIE \\
\cline { 2 - 4 } Acenaphthylene & $0.781 \pm 0.437$ & $0.440 \pm 0.581$ & $0.195 \pm 0.000$ \\
Acenapththene & $9.146 \pm 3.356$ & $2.978 \pm 0.431$ & $4.703 \pm 4.742$ \\
Fluorine & $0.552 \pm 1.006$ & $1.021 \pm 1.254$ & $4.003 \pm 4.505$ \\
Phenanthrene & $2.877 \pm 4.002$ & $0.802 \pm 0.651$ & $3.120 \pm 3.217$ \\
Anthracene & $0.939 \pm 0.387$ & $0.457 \pm 0.082$ & $1.140 \pm 0.609$ \\
Fluoranthene & $2.020 \pm 0.978$ & $8.310 \pm 7.318$ & $3.364 \pm 4.329$ \\
Pyrene & $4.787 \pm 3.367$ & $7.796 \pm 5.413$ & $1.573 \pm 0.912$ \\
Benzo (a) anthracene & $2.391 \pm 2.483$ & $0.401 \pm 0.000$ & $0.052 \pm 0.012$ \\
Chrysene & $2.673 \pm 2.384$ & $0.143 \pm 0.270$ & $0.572 \pm 0.000$ \\
Benzo (b) fluoranthene & $1.485 \pm 0.000$ & $3.669 \pm 2.923$ & $4.374 \pm 6.190$ \\
Benzo (k) fluoranthene & $9.948 \pm 8.668$ & $0.490 \pm 0.167$ & $4.680 \pm 4.024$ \\
Benzo (a) pyrene & $6.644 \pm 9.739$ & $0.412 \pm 0.326$ & $2.327 \pm 2.547$ \\
Indeno(1,2,3-cd)pyrene & $1.142 \pm 1.357$ & 0.000 & $0.372 \pm 0.656$ \\
Dibenz(a,h)anthracene & $1.187 \pm 0.931$ & $0.0713 \pm 0.00$ & $0.839 \pm 0.721$ \\
Benzo (ghi) perylene & $3.741 \pm 2.133$ & $3.099 \pm 1.654$ & $1.626 \pm 0.708$ \\
TOTAL & $11.399 \pm 10.311$ & $8.800 \pm 6.188$ & $3.697 \pm 2.492$ \\
\hline
\end{tabular}

Table 5. Summary of Correlation coefficients for seven different locations sample site for 16 PAHs (n=16).

\begin{tabular}{cccccccc}
\hline & OBSW & LDRW & RD & WDS & CMU & KLE & KPSH \\
\hline OBSW & 1 & 0.228 & 0.208 & $0.708^{* *}$ & 0.305 & $0.495^{*}$ & 0.208 \\
LDRW & & 1 & 0.225 & 0.058 & -0.203 & 0.013 & 0.186 \\
DR & & & 1 & -0.017 & -0.155 & 0.192 & 0.132 \\
WDS & & & & 1 & 0.343 & 0.312 & -0.034 \\
CHM & & & & & 1 & -0.046 & -0.091 \\
KLE & & & & & & 1 & 0.083 \\
KPSH & & & & & & 1 \\
\hline
\end{tabular}

** Correlation is significant at the 0.01 level, * Correlation is significant at the 0.05 level.

OBSW $=$ Oblogo solid waste disposal site, LDRW= Leach diluted with rain water, $\mathrm{RD}=$ Riveer Densu, WDS=Weija Dam site, CHE= Chemu Lagoon, $\mathrm{KLE}=$ Korle Lagoon and KPSH= Kpeshi Lagoon.

compounds were comparable at the various sites which is similar to similar work by Kanchanamayoon and Tatrahun (2009) [19]. The highest PAHs were recorded by compounds with molecular weights ranging from 128154 (i.e., naphthalene, acenaphthalene and acenaphthene) and those from 252-276 (i.e. [a] fluoranthene, perylene, benzo[a]pyrene, and benzo[g,h,i] perylene) which has also been reported by [20].

As far as the compositional pattern of PAHs is concern, the lagoon was generally dominated with all the PAHs. This relative abundance of low molecular weight PAHs (LPAHs) indicated that the PAHs were from petrogenic origin such as oil leakages or inadvertent oil spills [21].

Currently, there are no specific standards in Ghana for both inland and coastal waters for PAHs however evaluation of the toxicity that results from measured PAHs in the lagoons may be done by assessing their compliance with known international, national and provincial standards. According to the world health organization (WHO) the concentration of PAHs in water exceeding $0.05 \mu \mathrm{g} / \mathrm{L}$ indicates some level of toxicity [22].
From Table 3 and 4 it can be observed that all the individual PAH compounds analyzed exceeded the WHO accepted value of $0.05 \mu \mathrm{g} / \mathrm{L}$ and hence can be said that the Chemu, Korley and Kpeshi lagoon as well as Oblogo dumping site and it's environ are polluted with PAHs. Therefore consumption of fish or any other edibles from the lagoons, Densu River, and Weija Dam may prove detrimental to the health of consumers.

\subsection{Source Assessments}

The differences in the type of PAH compounds at the different sites indicate that there are potentially different sources of PAHs in the area; possibly including sewage outfalls, industrial wastewater, thermal combustion processes (e.g., cooking and heating oils, and coal buring) followed by atmospheric fallout, oil residues, vehicular emissions (e.g., automobiles and trucks), and biomass burning (e.g., fire woods, charcoal, etc) [20]. From inspection of the distribution of PAHs in the surface water alone, it is often difficult to differentiate between the sources of inputs. The ratios of specific parent $\mathrm{PAH}$ 
Table 6. Summary of Correlation coefficients for PAHs compounds in the water samples at seven different locations $(\mathrm{n}=13)$.

\begin{tabular}{|c|c|c|c|c|c|c|c|c|c|c|c|c|c|c|c|c|}
\hline & NAP & ACL & $\mathrm{AC}$ & $\mathrm{F}$ & $\mathrm{PH}$ & $\mathrm{AN}$ & FL & PYR & BZA & CHR & BZB & BZK & $\mathrm{BZaP}$ & Ind & Dib & BZghi \\
\hline NAP & 1 & 0.064 & 0.303 & -0.205 & -0.052 & -0.255 & $-0.504^{*}$ & -0.225 & -0.342 & 0.006 & -0.059 & -0.198 & -0.105 & -0.207 & -0.113 & -0.339 \\
\hline ACL & & 1 & -0.368 & 0.209 & -0.010 & -0.057 & -0.084 & $0.555^{*}$ & $0.528 *$ & -0.111 & $0.762 * *$ & $0.546^{*}$ & $0.570^{*}$ & 0.170 & $0.504^{*}$ & $0.046^{*}$ \\
\hline $\mathrm{AC}$ & & & 1 & -0.012 & 0.202 & -0.098 & -0.167 & -0.249 & -0.188 & 0.172 & -0.160 & -0.127 & -0.093 & -0.096 & -0.460 & -0.353 \\
\hline $\mathrm{F}$ & & & & 1 & $0.715^{* *}$ & 0.171 & -0.092 & 0.234 & $0.721 * *$ & -0.041 & 0.335 & 0.313 & -0.093 & -0.096 & -0.460 & -0.353 \\
\hline $\mathrm{PH}$ & & & & & 1 & 0.186 & -0.302 & -0.232 & 0.165 & -0.270 & -0.150 & -0.252 & -0.237 & 0.353 & -0.313 & -0.358 \\
\hline $\mathrm{AN}$ & & & & & & 1 & $0.624 *$ & 0.043 & 0.018 & -0.189 & -0.127 & -0.121 & -0.190 & -0.237 & 0.114 & 0.067 \\
\hline FL & & & & & & & 1 & 0.447 & 0.155 & 0.072 & 0.133 & 0.270 & 0.207 & -0.164 & $0.543 *$ & $0.640 * *$ \\
\hline BZA & & & & & & & & & 1 & 0.016 & $0.793 * *$ & $0.807 * *$ & $0.750 * *$ & $0.678 * *$ & 0.364 & $0.596 *$ \\
\hline CHR & & & & & & & & & & 1 & 0.216 & 0.399 & 0.411 & 0.176 & 0.074 & 0.241 \\
\hline BZB & & & & & & & & & & & 1 & $0.927 * *$ & $0.923 * *$ & $0.514^{*}$ & $0.495^{*}$ & $0.671 * *$ \\
\hline BZK & & & & & & & & & & & & 1 & $0.975 * *$ & $0.574 *$ & $0.481^{*}$ & $0.728 * *$ \\
\hline $\mathrm{BZaP}$ & & & & & & & & & & & & & 1 & $0.560 *$ & $0.527^{*}$ & $0.709 * *$ \\
\hline Ind & & & & & & & & & & & & & & 1 & 0.089 & 0.185 \\
\hline Dib & & & & & & & & & & & & & & & 1 & $0.877 * *$ \\
\hline
\end{tabular}

* Pearson Correlation is significant at the 0.05 level (1 tailed).

** Pearson Correlation is significant at the 0.01 level ( 1 tailed)

Naphthalene (NAP), Acenaphthylene (ACL), Acenapththene (AC), Fluorine (F), Phenanthrene (PH), Anthracene (AN), Fluoranthene (FL), Pyrene (PYR), Benzo (a) anthracene (BZA), Chrysene (CHR), Benzo (b) fluoranthene(BZB), Benzo (k) fluoranthene (BZK), Benzo (a) pyrene (BZaP), Indeno(1,2,3-cd)pyrene (Ind), Dibenz(a,h)anthracene (Dib), Benzo (ghi) perylene (BZghi).

Table 7. Summary of PAH ratios of water samples from sampling sites.

\begin{tabular}{cccccccc}
\hline RATIO & OBSW & LDRW & RD & WDS & CMU & KLE & KPSH \\
\hline AN/(AN+PH) & 0.599 & 0.330 & 0.552 & 0.775 & 0.683 & 0.948 & 0.747 \\
AN/(AN+F) & 0.665 & 0.789 & 0.320 & 0.413 & 0.414 & 0.912 & 0.481 \\
NAP/(NAP+ ACL) & 0.185 & 0.465 & 0.647 & 0.426 & 0.079 & 0.129 & 0.040 \\
NAP/(NAP+ AC) & 0.461 & 0.122 & 0.322 & 0.973 & 0.586 & 0.301 & 0.046 \\
FL/(FL+PYR) & 0.985 & 1.000 & 0.931 & 1.000 & 0.667 & 0.951 & 0.912 \\
BZA/(BZA+CHR) & 0.000 & 1.000 & 0.699 & 1.000 & 0.372 & 0.039 & 0.116 \\
BZaP/(BZghi) & 0.104 & 0.000 & 0.000 & 0.136 & 0.100 & 0.000 & 0.101 \\
BZB/(BZB+BZK) & 1.000 & 1.000 & 0.937 & 1.038 & 0.599 & 0.543 & 0.659 \\
Ind/(Ind+Dib) & 0.310 & 0.00 & 0.950 & 0.000 & 0.241 & 0.02 & 0.327 \\
\hline
\end{tabular}

Compound abbreviations in Table 6 .

compounds have also been identified to be one approach to distinguish between different sources of PAH in a particular environmental matrix, [20] and this method is used in the present study to characterize the PAH sources to the lagoon. Correlation analyses can also provide information about associations between sites, between the individual PAH compounds, and between some specific PAH compounds and heavy metals to determine com- 
mon origins.

\subsection{Site Correlations}

Correlation analyses between the sites' individual PAH compound levels $(\mathrm{n}=16)$ Table 5 , indicates no significant correlation between leach diluted with rain water, River Densu, Chemu, korle and kpeshi with any other site suggesting the unique origin of PAHs from these sites. Weija Dam Site correlates strongly with Oblogo solid waste site with significant coefficient of 0.708 at 0.01 levels. The correlation between the two sites for the individual PAH compounds is also reflected in the similarities of the compositional patterns at these two sites (see map).However, despite the distance apart of Korle lagoon to Oblogo solid waste disposal site, their correlation is only fair (0.495) at 0.05 level, suggesting that $\mathrm{PAH}$ origins from these sites are quite different to overcome the site proximity.

\subsection{PAH Interrelationships}

In order to assess PAH associations and their possible origins, correlation analyses were conducted among the concentration of the individual PAHs in the water samples. The results are summarized in Table 6. It is known that where two compounds have a common source, there is more likely to be a correlation between their concentrations [20]. Strong positive significant correlation was observed between individual PAHs. Benzo (a) Pyrene and Benzo (k) fluoranthene showed the highest PAH interrelationship with correlation coefficient of 0.975 followed by Benzo (b) fluoranthene/Benzo (k) fluoranthene and Benzo (a) Pyrene/Benzo (b) fluoranthene correlated with 0.927 and 0.923 respectively, significant at 0.01 levels. The following pairs also interrelated strongly at the significant level of 0.01: Benzo (a) Pyrene/ Pyrene (0.881), Dibenz (a,h) anthracene/Benzo (ghi) perylene (0.877), Benzo (k) fluoranthene/ Pyrene(0.857), Benzo (ghi) perylene/ Pyrene(0.833), Benzo (k) fluoranthene/ Benzo (a) anthracene(0.807), Benzo (b) fluoranthene/Pyrene (0.805), Benzo (b) fluoranthene/ Benzo (a) anthracene (0.793), Benzo (a) anthracene/pyrene (0.769), Benzo (b) fluoranthene/ Acenaphthylene (0.762), Benzo (a) Pyrene/ Benzo (a) anthracene (0.750), Pyrene/ Dibenz (a,h) anthracene(0.746 \pm 0.00$)$, Benzo (ghi) perylene/ Benzo (k) fluoranthene(0.728), Benzo(a)anthracene/Fluorine(0.721), Fluorine/Phenanthren $(0.715 \pm 0.03)$, Benzo (ghi) perylene/ Benzo (a) Pyrene (0.709), Indeno(1,2,3-cd)pyrene/ Benzo (a) anthracene(0.678), Benzo (ghi) perylene/ Benzo (b) fluoranthene(0.671), Benzo (ghi) perylene/ Fluoranthene(0.640).

At 0.05 level, significant positive correlation were also observed between PAHs with Anthracene/ Fluoranthene recording the highest correlation coefficient of 0.624 followed by Benzo (a) anthracene/ Benzo (ghi) perylene (0.596), Fluorine/ Indeno(1,2,3-cd)pyrene (0.588), Benzo (k) fluoranthene/ Indeno(1,2,3-cd)pyrene(0.574), Benzo (a) Pyrene / Acenaphthylene (0.570), Benzo (a) Pyrene/ Indeno(1,2,3-cd)pyrene (0.560), Pyrene/ Acenaphthylene (0.555), Benzo (k) fluoranthene/Acenaphthylene(0.546), Dibenz $(\mathrm{a}, \mathrm{h})$ anthracene/Fluoranthene(0.543), Acenaphthylene/ Benzo (a) anthracene (0.528), Dibenz (a,h) anthracene/ Benzo (a) Pyrene (0.527), Benzo (b) fluoranthene/ Indeno(1,2,3-cd)pyrene (0.514), Acenaphthylene/ Dibenz $(\mathrm{a}, \mathrm{h})$ anthracene $(0.504)$, Benzo (b) fluoranthene/ Dibenz (a,h) anthracene(0.495), Benzo (ghi) perylene/ Acenaphthylene(0.486) and Benzo (k) fluoranthene/ Dibenz $(a, h)$ anthracene $(0.481)$ in that order. The results reveal that these compounds, and to a lesser extent pyrene, were possibly derived from a common anthropogenic origin. No significant correlation was identified between Acenapththene and chrysene compound with any of the other PAH compounds measured which indicate other source of these two PAHs. In one case, Fluoranthene (FL) (containing 3 fused aromatic rings) showed inverse correlation with Naphthalene (at 0.01 level) (Table 6) containing 2 fused aromatic rings. It is speculated that some fraction of these compounds could be from the biodegradation of Fluoranthene (FL) by natural occurring population of water microorganisms since Fluoranthene is a polycyclic aromatic hydrocarbon (PAH) consisting of naphthalene and a benzene unit connected by a fourmembered ring. It is also known to occur naturally as a product of plant biosynthesis [27]. Further studies are required to verify this speculation.

\subsection{PAH Isomer Pair Ratios as Diagnostic Source Indicators}

The ratios of specific PAH compounds have been identified to possess the potential to distinguish natural and anthropogenic sources. [24-25]. To minimize confounding factors such as differences in volatility, water solubility, adsorption etc. ratio calculations are usually restricted to PAHs within a given molecular mass [24]. Yunker et al 2002 have summarized the literature on PAH ratios for petroleum, single-source combustion and some environmental samples and made the following conclusions. For mass 178, an anthrancene to anthracene plus phenanthrene $(\mathrm{AN} /\{\mathrm{AN}+\mathrm{PH}\})$ ratio of $>0.50$ usually is an indication of biomass \& coal combustion transition point. For mass 202, a fluoranthene to fluoranthene plus pyrene (FL/\{FL+PYR) ratio of $>0.50$ seems to be the characteristic of grass, wood or coal (biomass) \& coal combustion transition point, though not definite. For mass 228 , a benzo[a]anthracene to benzo[a] anthracene plus chrysene ratio $<0.20$ imply petroleum, $1.2-5.0$ indicates wood burning and coal burning [26], and $>0.35$ imply combustion [25]. The ratios of the above-specified PAHs in the Oblogo dumping sites, Leach diluted with 
rain water, Riveer Densu, Weija and Dam site as well as Chemu, Korle and Kpeshi lagoons were calculated and are shown in Table 6 . The $\mathrm{AN} / \mathrm{AN}+\mathrm{PH}$ ratios are all $>0.50$, suggesting grass, wood or coal (biomass) \& coal combustion sources of PAH from all eight sites. However, the smaller ratios (0.330) obtained for Leach diluted with rain water (LDRW) distinguishes it from the other sites. It appears there is mixed petroleum and combustion sources at this site. The BZA/(BZA+CRY), $\mathrm{AN} /(\mathrm{AN}+\mathrm{F}), \mathrm{FL} /(\mathrm{FL}+\mathrm{PYR}), \mathrm{BZB} /(\mathrm{BZB}+\mathrm{BZK}), \mathrm{Ind} /$ (In$\mathrm{d}+\mathrm{Dib}$ ), mixed ratios of $>0.01,0.4-0.5$ and $\geq 0.50$ re-echo the predominance of grass, wood (biomass), coal and petroleum combustion are the main source of PAH from the Oblogo solid waste dumping site down stream to Weija Dam down to Densu River. This confirms the belief that the burning of solid waste at Oblogo solid waste dump site is polluting the environment with PAHs. At the Chemu, Korle and Kpeshi Lagoons NAP/(NAP+ACL) and $\mathrm{BZaP} /(\mathrm{BZghi})$ ratio of $>0.10$ suggests a combustion source which is said to be affluent from Tama oil refinery.

The BZA/ $(\mathrm{BZA}+\mathrm{CHR})$ ratios whose interpretations are said to be more definitive [24] provided more distinctions between the sites. Based on $>0.35$ as the transi tion ratio, the calculated 0.375 suggests a combustion source for Chemu Lagoon, mixed unburned petroleum and combustion sources for Korle and Kpeshi. The mixed petroleum and combustion sources at this site is confirmed from the Ind/(Ind+Dib) fraction, where ratios of 0.241 (Chemu Lagoon) and 0.327 (Kpeshi Lagoon), which falls within the generally observed mixed-source ratio of $0.2-0.35$ for mixed petroleum/ combustion origin of pollution are observed. At Korle Lagoon ratio of $>0.10$ implying unburned petroleum source has also been observed.

Despite the lack of consistency in some cases, there seems to be a general consensus by all the ratio indicators that combustion is the dominant source of PAH input into the lagoon. Although not conclusive, there is also an indication of petrogenic source contributions to sites such as chemu, korle, kpeshi as well as Weija Dam (Table 6). Variations in additional input sources (e.g., high or medium temperature combustion processes, different fossil materials) may also account for the differences in the composition pattern of PAHs between sampling sites (Table 7) [27]. Despite the apparent dominance of combustion and wood/coal burning (pyrogenic origin) as the major source of anthropogenic PAH to the Oblogo solid waste dump site, weija Dam, River Densu, Chemu, Korle and Kpeshi Lagoons sites (using the ratio indicators above). The $\mathrm{AN} /(\mathrm{AN}+\mathrm{F})$ and $\mathrm{NAP} /(\mathrm{NAP}+$ ACL) ratios suggests petroleum combustion for Waija Dam, Chemu and Kpeshi sites (Table 7). It is therefore possible that combustion of liquid fossil fuel is the major source of PAH to the lagoons and the other sites.

NB: Source Patterns from the literature [24-25]; $>0.10$ : combustion source; <0.10: unburned petroleum source, $>0.50$ : biomass \& coal combustion, $0.4-0.5$ : petroleum combustion, $<0.40$ : unburned petroleum, $>0.35$ : combustion, $0.20-0.35$ : mixed petroleum/ combustion $<0.2$ : unburned petroleum source, 1.2-5.0: wood burning and coal burning [26].

\section{Conclusions}

Results obtained from the study clearly demonstrated that the leach from Oblogo solid waste disposal site and its environs as well as Chemu, Korle and Kpeshi Lagoons are polluted by Polycyclic Aromatic Hydrocarbons with concentration ranging from below detection level to $14.587 \mu \mathrm{g} / \mathrm{L}$. However, seven carcinogenic PAHs were detected in different concentrations from the various sites. It is important that, those PAHs promulgated by USEPA to be toxic and need to be investigated in developing countries. Acenaphthene, Anthracene, Benzo [a]anthracene, Benzo[b]fluoranthene, Chrysene, Phenanthrene occurred at the various sites above the safety level set by WHO. It can be concluded that people living around the Oblogo solid waste disposal site, who swim and bath in the downstream of River Densu would be exposed to these PAHs and may be at risk of their harmful effects.

The average concentration of PAHs in the water ranged from $0.552 \mu \mathrm{g} / \mathrm{L}$, for Acenapththene to 11.399 $\mu \mathrm{g} / \mathrm{L}$ for Benzo (ghi) perylene of the Chemu Lagoon, $0.00 \mu \mathrm{g} / \mathrm{L}$ for Benzo (a) Pyrene to $8.800 \mu \mathrm{g} / \mathrm{L}$ for Benzo (ghi) perylene (Korle Lagoon) and $0.052 \mu \mathrm{g} / \mathrm{L}$ for Pyrene to $4.703 \mathrm{ug} / \mathrm{L}$ for Acenaphthylene of the Kpeshi Lagoon.

Good site correlations shown by water samples from Oblogo solid waste site and Weija Dam which derive their source mainly from burning of biomass and coal and combustion processes demonstrate how open dumping and burning procedure used in Ghana can pollute the environment. Other site far apart seem to inter-relate in terms of their PAH levels. Close relationships were also found between all individual PAH compounds except Acenapththene and chrysene which did not show any correlation with other PAHs. Benzo (a) Pyrene and Benzo (k) fluoranthene showed the highest PAH-PAH associations. The correlation and ratios of PAHs results revealed that these compounds were possibly derived from a common anthropogenic origin. There seems to be a general consensus from some three PAH-PAH ratio indicators that combustion and burning of biomass are the dominant source of PAH input into the Oblogo dumping sites down stream and the three lagoons studied. Although not conclusive, there is also an indication of petrogenic source contributions from some sites especially, the Chemu, Korle and Kpeshi Lagoons. Particularly in the vicinity of the Tema oil refinery. 


\section{Acknowledgment}

The authors wish to express their sincere appreciation to the staff of Centre for Scientific and Industrial Research (CSIR), Environmental Division (ED), Water Research Institute (WRI) and the Organic Laboratory for their kind assistance in the analysis of the samples. Sincere thanks also go to the entire laboratory staff of Chemistry Department University of Cape Coast for their support. Finally, we wish to thank the government of Ghana for financial assistance.

\section{References}

[1] NPI, "Australian national pollution inventory substance profile," Department of the Environment and Heritage, 2001.

[2] New York City Department of Sanitation (NYCDS), "Solid waste management plan," Environmental Impact, New York: Author, pp. 12-14, 1991.

[3] M. Gochfeld, "Health implications of solid waste management," In Environmental Medicine, eds. S. Brooks, et al. St. Louis, MO: Mosby, pp. 104-112, 1995.

[4] Mechanical Biological Treatment Welsh Assembly (MBTWA), "Mechanical biological treatment," Environment Countryside and Planning Website, Welsh Assembly, pp 21-32, 2005.

[5] Arias-Estevez, "Sorption of PAHs to colloid dispersion of humic substance in water," McGraw Hill Higher Education, Fourth Edition, pp. 315, 2007.

[6] Agency for toxic substances and disease registry (ATSDR), "Toxicology profile for polycyclic aromatic hydrocarbons (PAHs),' Atlanta, ga: U.S department for health and human service, public health service, 1995.

[7] D. R. Shahunthala, J. M. Sweezey, V. P. Hodson, M. Boudreau, S. C. Courtenay, K. Lee, T. King and J. A. Dixon, "Influence of salinity and fish species on PAH uptake from dispersed crude oil," Vol. 52(10), pp. 1182-1189, 2006.

[8] C. A. Anyakora, K. A. Ogbeche, P. Palmer, H. Coker, G. Ukpo and C. Ogah, "A screen for Benzo[a]pyrene, a carcinogen, in the water samples from the Niger Delta region," Nig. J. Hosp. Med., Vol.14, pp. 288-293, 2004.

[9] S. A. Perlin, R. Woodrow-Setzer, J. Creason and K. Sexton, "Polycyclic Aromatic Hydrocarbons (PAHs), Appendix A," Environmental Science and Technology, Vol. 29, pp. 69-80, 1995.

[10] C. Baird, "Environmental chemistry," New York: W. H. Freeman and Company, pp. 65-74, 1995.

[11] C. A. Aynankora, K. A. Ogbeche, P. Palmer, H. Coker and G. Ukpo, "Analysis of polynuclear aromatic hydrocarbons in sediment samples of Niger delta region," Chemosphere, Vol. 60, pp. 990-997, 2005.

[12] Agency for Toxic Substances and Disease Registry (ATSDR), "Toxicological profile for polycyclic aromatic hydrocarbons (PAHs)," Atlanta, GA: U. S. Department of Health and Human Services, Public Health Service, 1990.

[13] World Health Organization (WHO), "Polynuclear aro- matic hydrocarbons. In: Guidelines for drinking-water quality,' Health criteria and other supporting information. Geneva, World Health Organization 2nd ed., Vol. 2, pp. 123-152, 1998.

[14] S. King, J. S. Meyer and A. R. J. Andrews, "Screening method for polycyclic aromatic hydrocarbons in soil using hallow fibre membrane solvent micoextraction,' Journal of Chromatography A, Vol. 982, pp. 201-208, 2002.

[15] American Public Health Association, "Standard method for the examination of water and waste water,' 20th Edition, pp. 6/80-6/81, 2005.

[16] D. O. Alonge, "Carcinogenic polynuclear hydrocarbon determined in Nigeria Kundi (smoked dried meat)," Journal of the Science of Food and Agriculture, Vol. 43, pp. 167-173, 1998.

[17] F. Douglass, "GC/MS analytical methods," Academic Press INC, New York, 2nd Edition, pp. 112-115, 2004.

[18] S. D. Ramachandran, M. J. Sweezey, P. V. Hodson, M. Boudreau, S. C. Courtenay, K. Lee, T. King and J. A. Dixon, "Influence of salinity and fish species on PAH uptake from dispersed crude oil Marine Pollution Bulletin,'” Vol. 52, No. 10, pp. 1182-1189, 2006.

[19] W. Kanchanamayoon and N. Tatrahun, "Extraction of eleven polycyclic aromatic hydrocarbons in water samples,' Journal of Environmental Science and Technology, Vol. 2, No. 2, pp. 95-99, 2009.

[20] E. Gilbert, D. K. Dodoo, F. Okai-Sam, D. K. Essumang and E. K. Quagraine, "Characterization and source assessment of heavy metals and Polycyclic Aromatic Hydrocarbons (PAHs) in sediments of the Fosu Lagoon,", Ghana Journal of Environmental Science and Health Part A, Vol. 41, pp. 2747-2775, 2006.

[21] D. Okoro, "Source determination of polynuclear aromatic hydrocarbons in water and sediment of a creek in the Niger Delta region,' African Journal of Biotechnology, Vol. 7, No. 3, pp. 282-285, 2008.

[22] P. Bikey, T. Mandy and B. Presley, "Exposure analysis and environmental epidemiology,' Endangered, sj. Jea, Vol. 289, pp. 268-272, 2001.

[23] U. S. EPA (U.S. Environmental Protection Agency), "Ambient Water Quality Criteria for Fluoranthene. Office of Water Regulations and Standards," Criteria and Standards Division, Washington, DC. EPA Vol. 440, pp. 5-80-049, 1980.

[24] L. Zhu and J. Wang, "Pattern and Sources of PAHs pollution in Sediment of Hangzhou, China," Organohal Comp., Vol. 66, pp. 291-296, 2004.

[25] M. B. Yunker, R. W. Macdonald, R. Vingarzan, R. H. Mitchell, D. Goyette and S. Sylvestre, "PAHs in the Fraser River basin; a critical appraisal of PAH ratios as indicators of PAH source and composition," Org. Geochem., Vol. 33, pp. 489-515, 2002.

[26] W. A. Maher and J. Aislabie, "Polycyclic aromatic hydrocarbons in near shore marine sediments of Australia," Science of the Total Environment, Vol. 112, pp. 143-164, 1992.

[27] J. L. Zhou and K. Maskaoui, "Distribution of polycyclic aromatic hydrocarbons in water and surface sediments from Daya Bay," China, Environmental Pollution, Vol. 121, pp. 269-281, 2003. 


\section{Appendix}

\begin{tabular}{ccccc}
\hline & SUMARRY OF & PAH CONCENTRATIONS IN CHEMU \\
\hline PAHS & \multicolumn{3}{c}{ CONCENTRATION IN ug/L } \\
\hline Naphthalene & 1 & 2 & 3 & AVERAGE \pm SD \\
Acenaphthylene & 0.862 & 1.481 & 0.000 & $0.781 \pm 0.437$ \\
Acenapththene & 12.739 & 6.092 & 8.609 & $9.146 \pm 3.356$ \\
Fluorine & 0.000 & 0.117 & 1.539 & $0.552 \pm 1.006$ \\
Phenanthrene & 7.496 & 0.682 & 0.454 & $2.877 \pm 4.002$ \\
Anthracene & 0.351 & 0.195 & 0.929 & $0.939 \pm 0.387$ \\
Fluoranthene & 3.195 & 1.583 & 3.350 & $2.020 \pm 0.978$ \\
Pyrene & 7.726 & 1.529 & 1.329 & $4.787 \pm 3.367$ \\
Benzo (a) anthracene & 1.828 & 0.238 & 5.107 & $2.391 \pm 2.483$ \\
Chrysene & 5.906 & 1.493 & 0.620 & $2.673 \pm 2.384$ \\
Benzo (b) fluoranthene & 4.456 & 0.000 & 0.000 & $1.485 \pm 0.000$ \\
Benzo (k) fluoranthene & 19.863 & 3.803 & $9.948 \pm 8.668$ \\
Benzo (a) Pyrene & 17.827 & 2.079 & 0.026 & $6.644 \pm 9.739$ \\
Indeno(1,2,3-cd)pyrene & 2.704 & 0.252 & 0.469 & $1.142 \pm 1.357$ \\
Dibenz(a,h)anthracene & 0.195 & 1.130 & 2.056 & $1.187 \pm 0.931$ \\
Benzo (ghi) perylene & 5.357 & 1.323 & 4.544 & $3.741 \pm 2.133$ \\
& 23.091 & 3.604 & 7.502 & $11.399 \pm 10.311$ \\
\hline
\end{tabular}

\begin{tabular}{ccccc}
\hline \multicolumn{5}{c}{ SUMARRY OF PAH CONCENTRATIONS IN KORLE } \\
\hline PAHS & \multicolumn{4}{c}{ CONCENTRATION IN ug/L } \\
\hline Naphthalene & 1 & 2 & 3 & AVERAGE \pm SD \\
Acenaphthylene & 1.101 & 0.209 & 0.011 & $0.440 \pm 0.581$ \\
Acenapththene & 4.952 & 4.343 & 0.000 & $2.978 \pm 0.431$ \\
Fluorine & 0.283 & 0.310 & 2.469 & $1.021 \pm 1.254$ \\
Phenanthrene & 1.389 & 0.915 & 0.102 & $0.802 \pm 0.651$ \\
Anthracene & 0.548 & 0.389 & 0.436 & $0.457 \pm 0.082$ \\
Fluoranthene & 10.186 & 0.236 & 14.508 & $8.310 \pm 7.318$ \\
Pyrene & 3.998 & 5.397 & 13.995 & $7.796 \pm 5.413$ \\
Benzo (a) anthracene & 0.000 & 0.000 & 1.202 & $0.401 \pm 0.000$ \\
Chrysene & 0.403 & 0.021 & 0.000 & $0.143 \pm 0.270$ \\
Benzo (b) fluoranthene & 4.129 & 5.779 & 1.100 & $3.669 \pm 2.923$ \\
Benzo (k) fluoranthene & 0.235 & 0.569 & 0.395 & $0.490 \pm 0.167$ \\
Benzo (a) Pyrene & 0.974 & 0.102 & 0.160 & $0.412 \pm 0.326$ \\
Indeno(1,2,3-cd)pyrene & 0.000 & 0.000 & 0.000 & 0.000 \\
Dibenz(a,h)anthracene & 0.214 & 0.000 & 0.000 & $0.0713 \pm 0.00$ \\
Benzo (ghi) perylene & 0.856 & 3.735 & 3.707 & $3.099 \pm 1.654$ \\
& 1.834 & 13.66 & 10.906 & $8.800 \pm 6.188$ \\
\hline
\end{tabular}

\begin{tabular}{|c|c|c|c|c|}
\hline \multicolumn{5}{|c|}{ SUMARRY OF PAH CONCENTRATIONS IN KPESHIE } \\
\hline PAHS & & CONC & IN ug/L & \\
\hline & 1 & 2 & 3 & AVERAGE \\
\hline Naphthalene & 0.058 & 0.000 & 0.000 & $0.195 \pm 0.000$ \\
\hline Acenaphthylene & 1.423 & 10.158 & 2.592 & $4.703 \pm 4.742$ \\
\hline Acenapththene & 1.352 & 1.470 & 9.214 & $4.003 \pm 4.505$ \\
\hline Fluorine & 1.120 & 6.832 & 1.409 & $3.120 \pm 3.217$ \\
\hline Phenanthrene & 1.174 & 1.732 & 0.516 & $1.140 \pm 0.609$ \\
\hline Anthracene & 0.377 & 8.329 & 1.385 & $3.364 \pm 4.329$ \\
\hline Fluoranthene & 0.746 & 2.552 & 1.422 & $1.573 \pm 0.912$ \\
\hline Pyrene & 0.000 & 0.070 & 0.087 & $0.052 \pm 0.012$ \\
\hline Benzo (a) anthracene & 0.000 & 1.715 & 0.000 & $0.572 \pm 0.000$ \\
\hline Chrysene & 1.531 & 0.116 & 11.475 & $4.374 \pm 6.190$ \\
\hline Benzo (b) fluoranthene & 0.062 & 7.435 & 6.543 & $4.680 \pm 4.024$ \\
\hline Benzo (k) fluoranthene & 0.000 & 1.690 & 5.292 & $2.327 \pm 2.547$ \\
\hline Benzo (a) Pyrene & 0.000 & 0.094 & 1.022 & $0.372 \pm 0.656$ \\
\hline Indeno(1,2,3-cd)pyrene & 1.512 & 0.078 & 0.928 & $0.839 \pm 0.721$ \\
\hline Dibenz(a,h)anthracene & 1.930 & 2.119 & 0.809 & $1.626 \pm 0.708$ \\
\hline Benzo (ghi) perylene & 1.511 & 6.362 & 2.948 & $3.697 \pm 2.492$ \\
\hline
\end{tabular}

